UDC 620.9:662.92; 538.953-405

\title{
Modeling the processes of combustion products formation in the coal-dust flame
}

\author{
A. Askarova, S. Bolegenova*, V. Maximov, S. Aidabol, N. Otynshyeva \\ Institute of Experimental and Theoretical Physics, Al-Farabi Kazakh National University, \\ 71, al-Farabi Ave., 050040, Almaty, Kazakhstan \\ *e-mail: saltanat.bolegenova@kaznu.kz
}

\begin{abstract}
In this paper deals with development and application the numerical model for solution of processes at combustion chamber of the industrial boiler. The combustion chamber of the BKZ-75 boiler installed at Shakhtinskaya Thermal Power Plant (Karaganda, Kazakhstan) was chosen as the object of the research. As a result of computational experiments obtained distribution of concentrations of harmful substances: $\mathrm{CO}_{2}, \mathrm{CO}, \mathrm{NO}$ throughout the volume of the combustion chamber and on an output from it. In addition, the authors received a distribution of oxygen depending on the height of the combustion chamber. The minimum and maximum values of the investigated characteristics are established. The dynamics of the change in the characteristics of the heat and mass exchange process in the volume of the researched combustion chamber is shown. Obtained results give quantitative information on the amount of combustion products including harmful substances. The numerical model becomes a tool for investigation and design of combustion chambers with high-efficiency and reliable operation of boiler at thermal power plants. The results of this research has high practical importance, they allow studying heat exchange processes occurring in combustion in real geometry areas (combustion chambers of power plants).
\end{abstract}

Key words: combustion chamber, numerical modeling, temperature, coal, thermal power plant.

PACS: 65.00

\section{Introduction}

Now the main share of energy is made due to burning or processing of natural raw materials coal, oil, gas, combustible slates, and peat. Any of modern ways of production and use of energy is to a greater or lesser extent connected with certain negative impacts on environment. In an energy drink, the main sources of pollution are thermal power plants energy production on which is followed first by pollution of atmospheric air [1-3].

The power system of Kazakhstan is presented mostly by thermal power stations more than $70 \%$ of total amount of the electric power are generated. Thermal power stations work on solid fuel when pulverized coal combustion is predominant. Also natural gas and black oil can be used. Tendency of low grade coals usage to increase in domestic industry, it becomes especially important to develop and introduce new energy-saving technologies of solid fuel consumption and reduction in pollutant substance emissions. Applied technology of direct burning of low-grade coals in furnaces does not provide demanded reliability of working equipment and protection of environment from harmful combustion products due to approximately $50 \%$ of pollutant emissions from stationary sources comes from thermal power enterprises and about $33 \%$ are emitted by ferries and nonferrous metallurgy and mining [4-5]. Industrial implementation of any new technology is not possible without preliminary analysis of advantages and disadvantages suggested method. The rapid development in computer sciences gives the advance to computational techniques to be used for simulation of complex combustion processes in industrial furnaces. Products of combustion contain different harmful substances and the emission of these components grows in to a great problem. Industrial development causes an increase in hydrocarbonaceous fuels' consumption. These fuels contain harmful and poisonous components such as carbonic oxide (CO), nitric oxide (NO), sulphur dioxide, acid sulphate, lead combinations and different hydrocarbons etc. To decrease emissions of harmful substances various methods are applied, including special fire regimes (organization of combustion process), which suppresses the formation of harmful substances in flame and two-stage burning, when the burners work with low air surplus. In this way 
numerical experiments became one of the most effective and suitable means for detail analysis and in-depth study of physical and chemical phenomena. In contrast to construction of an operating reduced model of the chamber, the three-dimensional modeling with the application of modern computer technology enables to carry out deep analysis of all chamber's parameters and save time and finances. At the same time, without additional inputs, it is possible to obtain the full set of characteristics of a convective heat and mass transfer process in reactive media, intervene flexibly in the process at any stage and reproduce separate technical solutions (the configuration of the fire chamber and assembly and construction burners), to model the formation of harmful dust and gaseous emissions and to investigate the influence of previous preparation of coal on its ignition and combustion stabilization.

About $50 \%$ of the consumed fuel are the share of production of heat and the electric power in Kazakhstan. The general power of the electro generating sources in the Republic of Kazakhstan makes more than 18 thousand MW, which about $87 \%$ of a basis make thermal power plant [6-7].

In this regard, researches in the field of progressive technologies on improvement of power stations on burning of coal-dust fuel and use of alternative methods of the organization of process of burning are the most actual for all power complex of the Republic of Kazakhstan now [8].

\section{Numerical simulation}

Computing experiments in this work were made on the basis on the solution of the three-dimensional equations of convective heat- and mass transfer taking into account distribution of heat, thermal radiation, chemical reactions and multiphase of the environment.

To describe the motion of three-dimensional reacting flows in the chamber uses a system of differential equations:

1. The continuity equation

$$
\frac{\partial \rho}{\partial \tau}=-\frac{\partial}{\partial x_{i}}\left(\rho u_{i}\right)
$$

2. The law of conservation of momentum (Navier-Stokes):

$$
\begin{gathered}
\frac{\partial}{\partial \tau}\left(\rho u_{i}\right)=-\frac{\partial}{\partial x_{j}}\left(\rho u_{i} u_{j}\right)+ \\
+\frac{\partial}{\partial x_{j}}\left(\tau_{i j}\right)-\frac{\partial p}{\partial x_{j}}+\rho f_{i},
\end{gathered}
$$

where $\tau_{i, j}$ - viscous stress tensor, $f_{i}-$ the external force;

3. The law of conservation of energy (the first law of thermodynamics):

$$
\begin{gathered}
\frac{\partial}{\partial t}(\rho h)=-\frac{\partial}{\partial x_{i}}\left(\rho u_{i} h\right)-\frac{\partial q_{i}^{r e s}}{\partial x_{j}}+ \\
+\frac{\partial p}{\partial t}+u_{i} \frac{\partial p}{\partial x_{i}}+\tau_{i j} \frac{\partial u_{j}}{\partial x_{i}}+S_{q}
\end{gathered}
$$

where $h$ - specific enthalpy, $q_{i}^{\text {res }}$ associated with energy transfer by conduction and diffusion flux of matter, $S_{q}-$ a source of energy due to chemical reactions and radiative heat transfer;

4. The conservation of components of the mixture:

Write the equation describing the concentration of a component mixture in the general form as follows:

$$
\begin{aligned}
& \frac{\partial}{\partial t}\left(\rho c_{n}\right)+\frac{\partial}{\partial x_{i}}\left(\rho u_{i} c_{n}\right)= \\
& =\frac{\partial}{\partial x_{i}}\left[\frac{\mu_{e f f}}{\sigma_{c_{n, e f f}}} \frac{\partial c_{n}}{\partial x_{i}}\right]+S_{c_{n}},
\end{aligned}
$$

where $S_{c}$ - the source term , taking into account the contribution of the chemical reactions in the change in the concentration of components .

The turbulent flow pattern is described by means of a two-equation $k-\varepsilon$ turbulence model, where $k$ turbulent kinetic energy, $\varepsilon$-turbulent energy dissipation [9-13]. A standard $k-\varepsilon$ model of turbulence has been used to close off the system and model turbulent viscosity.

$$
\begin{gathered}
\frac{\partial(\bar{\rho} k)}{\partial t}=-\frac{\partial\left(\bar{\rho} \bar{u}_{j} k\right)}{\partial x_{j}}+ \\
+\frac{\partial}{\partial x_{j}}\left[\frac{\mu_{e f f}}{\sigma_{k}} \frac{\partial k}{\partial x_{j}}\right]+P-\bar{\rho} \varepsilon
\end{gathered}
$$


Calculation of turbulent flows with chemical reactions is based on the knowledge of chemical kinetics and modeling methods of turbulent transfer processes [14].

Calculation domain is proposed according to power boiler BKZ-75 Shakhtinskaya thermal power station (Kazakhstan). The domain is depicted in figure 1, where dimensions and discretization of structured grid are shown.

The boiler of the BKZ - 75 - vertically water pipe, is manufactured by the Barnaul boiler plant, with a productivity of $75 \mathrm{t} /$ hour $(51,45 \mathrm{Gcal} / \mathrm{h})$, temperature of superheated steam $440^{\circ} \mathrm{C}$ and pressure of superheated couple $39 \mathrm{kgfs} / \mathrm{cm}^{2}$. Influence of volatiles essentially at an initial stage of burning fuel: the exit of volatiles is higher, the fuel ignites quicker and the more deeply it burns out. But the release of volatile substances must not exceed certain standards adopted in each region. Except the main components, which are formed because of burning organic fuel, emissions of combined heat and power plant contain dust particles of various structure, nitrogen oxides, oxides of metals, gaseous products of incomplete combustion of fuel [16-18].

To solve the problem of air pollution dust and gas emissions, it is necessary to develop the environmentally "clean" energy burning fuel. In this regard, the study of the concentration characteristics of harmful substances in the combustion products is an urgent task.
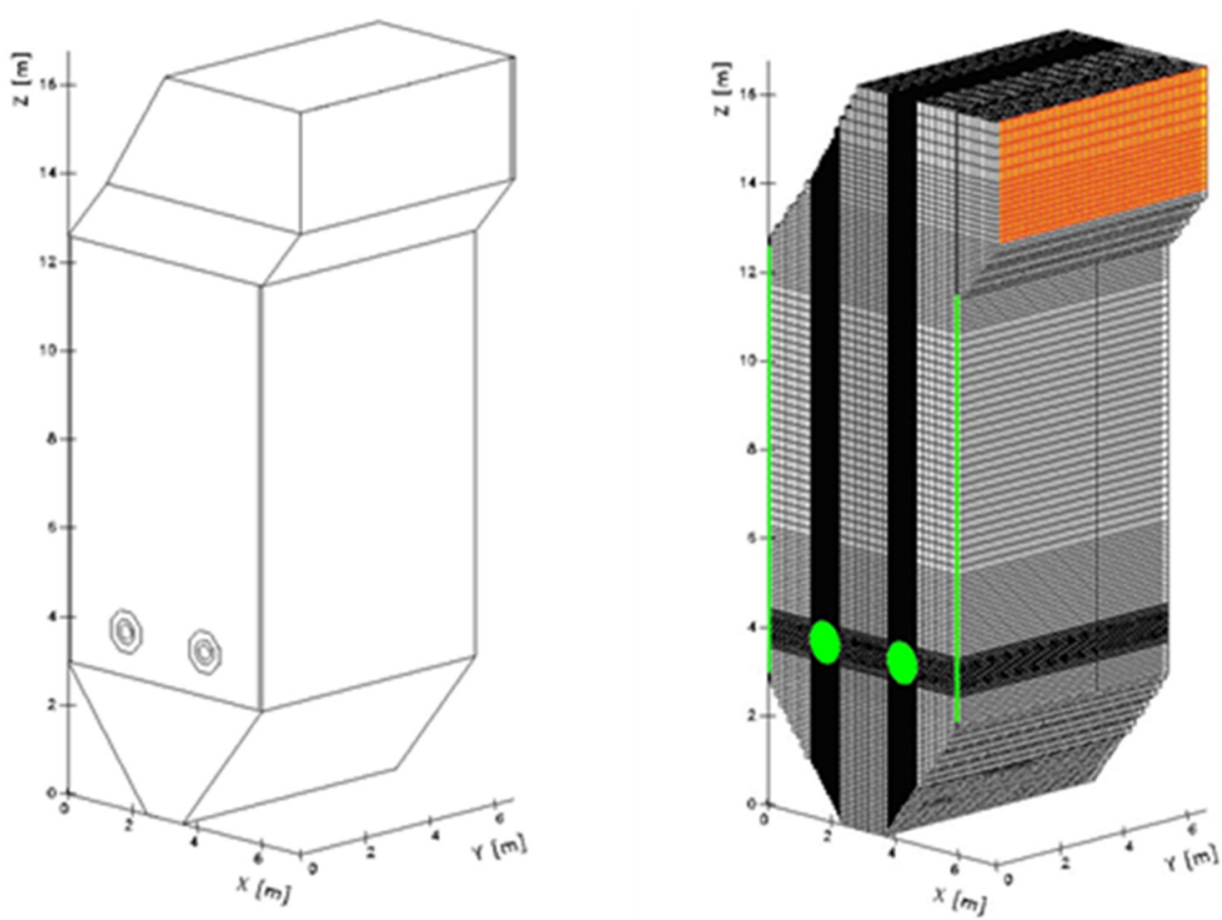

Figure 1 - Computational domain and finite volume discretization grid of the combustion chamber

\section{Results and discussion}

Figures 2-6 present the results of computational experiments investigating mass transfer characteristics and concentration of harmful dust and gas emissions in the combustion chamber of the boiler BKZ- 75 Shakhtinskaya CHP.

From all the nitrogen oxides in the flue assay device is viewed mainly nitrogen monoxide NO, which is formed largely from the combustion of coal. At relatively low temperatures, preferably nitrogen dioxide NO2 formation, but because of the low rate of its formation and the relatively short time of passage of the flue gases of the boiler, its content in the amount of nitrogen monoxide $\mathrm{NO}$ at the combustion chamber does not exceed $5 \div 10$ percent [19].

Figures 2-3 shows the distributions of concentrations of nitric oxide (NO) in different sections of the combustion chamber. 
Figure 2 (a, b) show the distributions of concentrations of nitric oxide (NO) in different sections of the combustion chamber.

Analysis figures $2(\mathrm{a}, \mathrm{b})$ shows that a maximum area of nitric oxide, $\mathrm{NO}$, is a region of high temperatures and intense eddy currents. For the study of the combustion chamber such area is in the area of the burners at the height of $\mathrm{z}=4.0$ meter. Intensive mixing of fuel and oxidant produced by turbulent flow of injected fuel mixture near the burner, and the high temperature in the core of the flame $\left(\sim 1200^{\circ} \mathrm{C}\right)$, create favorable conditions for the formation of nitrogen oxides. In this area, the NO concentration reaches maximum values of $2201 \mathrm{mg} / \mathrm{Nm}^{3}$. As seen in figure 3, as the pulverized coal flame passage to the exit of the combustion chamber there is a uniform reduction in the concentration of $\mathrm{NO}$, as this area contains less oxygen and a fuel component. Besides, the temperature is reduced and the height of the combustion chamber, thereby reducing the rate of formation of nitric oxide.

At the outlet from the combustion chamber average value of the nitrogen oxide NO concentration is $550 \mathrm{mg} / \mathrm{Nm}^{3}$. It meets standards of maximum concentration limit for furnace cameras of coppers of the thermal power plants working at coal-dust fuel.

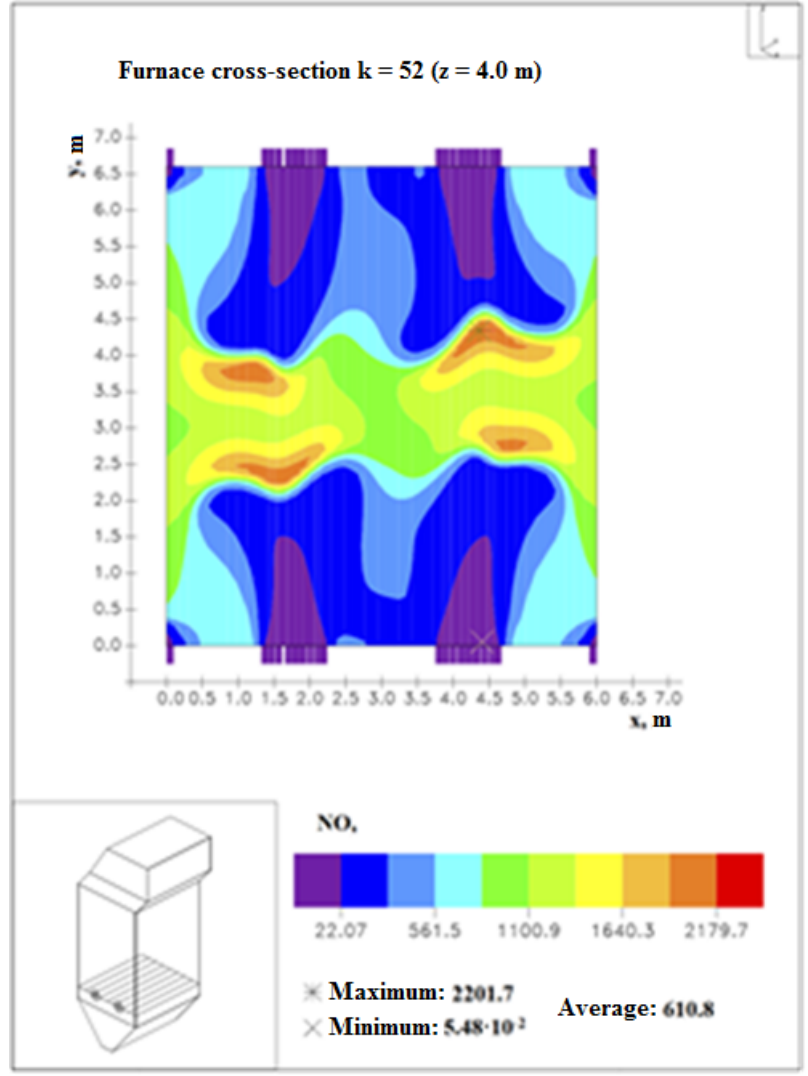

a)

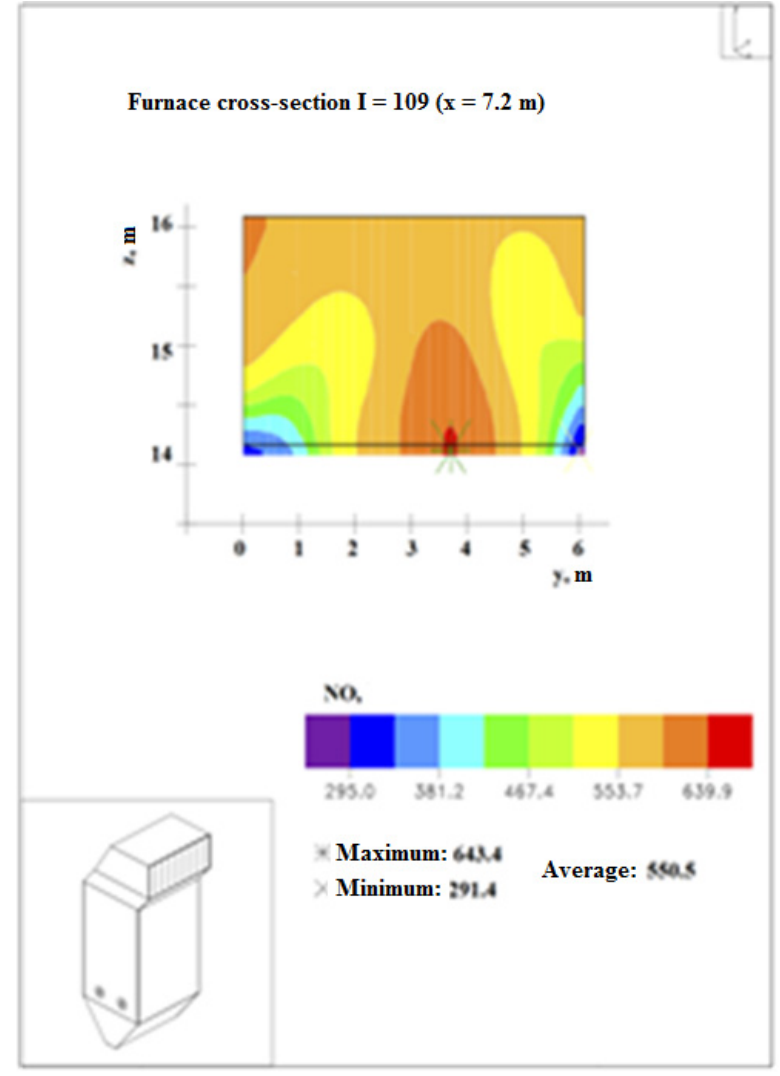

b)

Figure 2-NO concentration distribution in cross sections: a) burners, b) at the outlet of the combustion chamber 


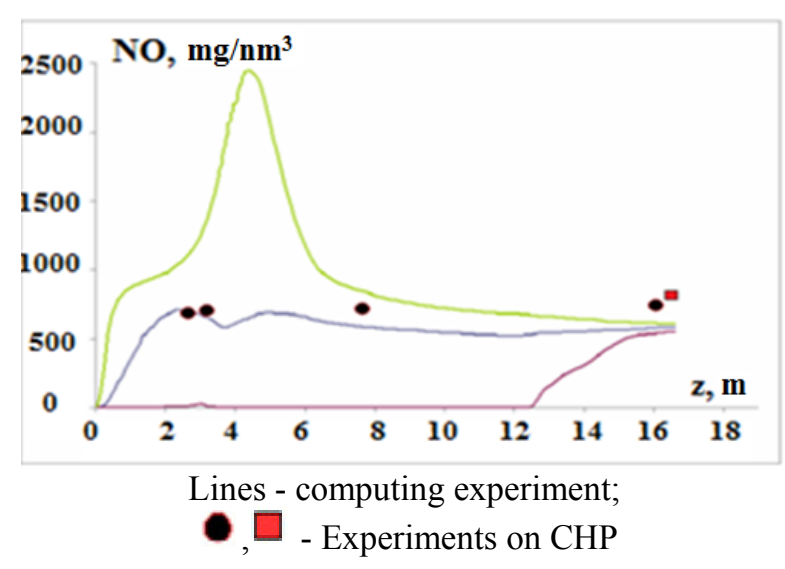

Figure 3 - Distribution of concentration of $\mathrm{NO}$ on height of the furnace camera

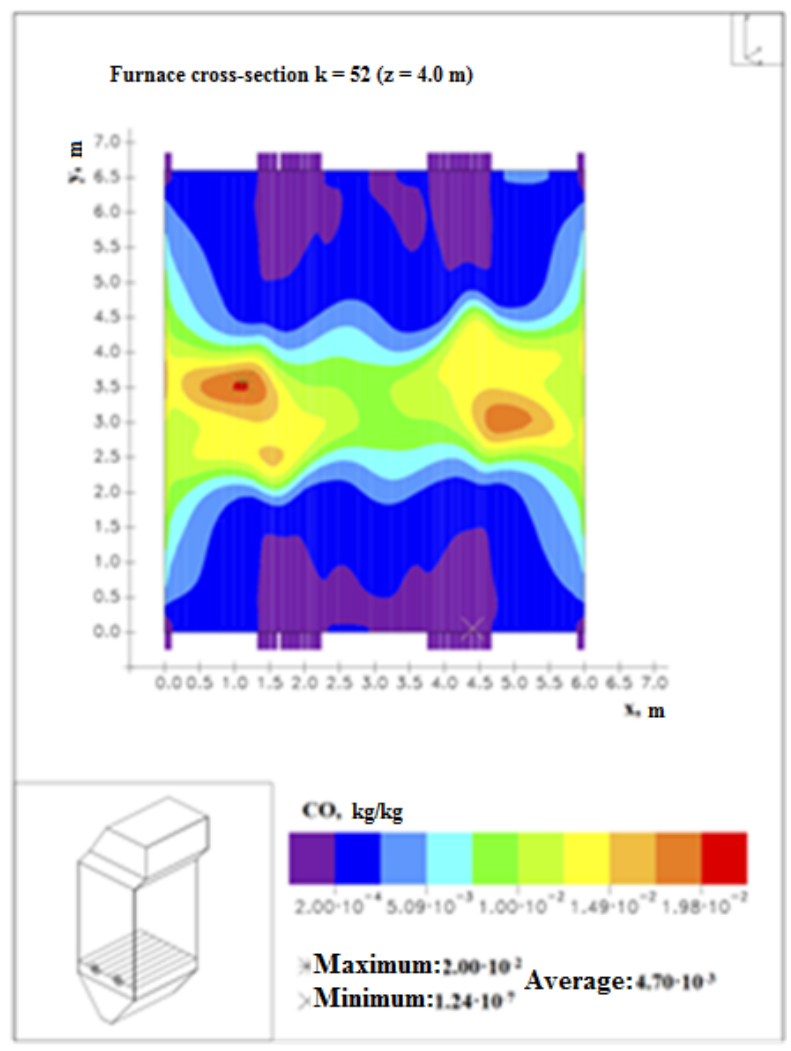

a)
Figures 4-5 show the distributions of concentrations of carbon monoxide $(\mathrm{CO})$ in sections of the burners and the outlet of the combustion chamber [20].

The main result of the combustion process of carbon at high temperatures is a compound of oxygen with carbon pulverized coal to form carbon monoxide $\mathrm{CO}$, carbon dioxide or $\mathrm{CO}_{2}$ [21].

The special importance when burning coal-dust fuel is gained by reaction of oxidation of carbon to $\mathrm{SO}$ carbon monoxide. Because, further $\mathrm{CO}$ reacting with air oxygen, "burns down" to $\mathrm{CO} 2$, marking out thus the maximum value of energy, equal 571 $\mathrm{kJ} / \mathrm{mol}$.

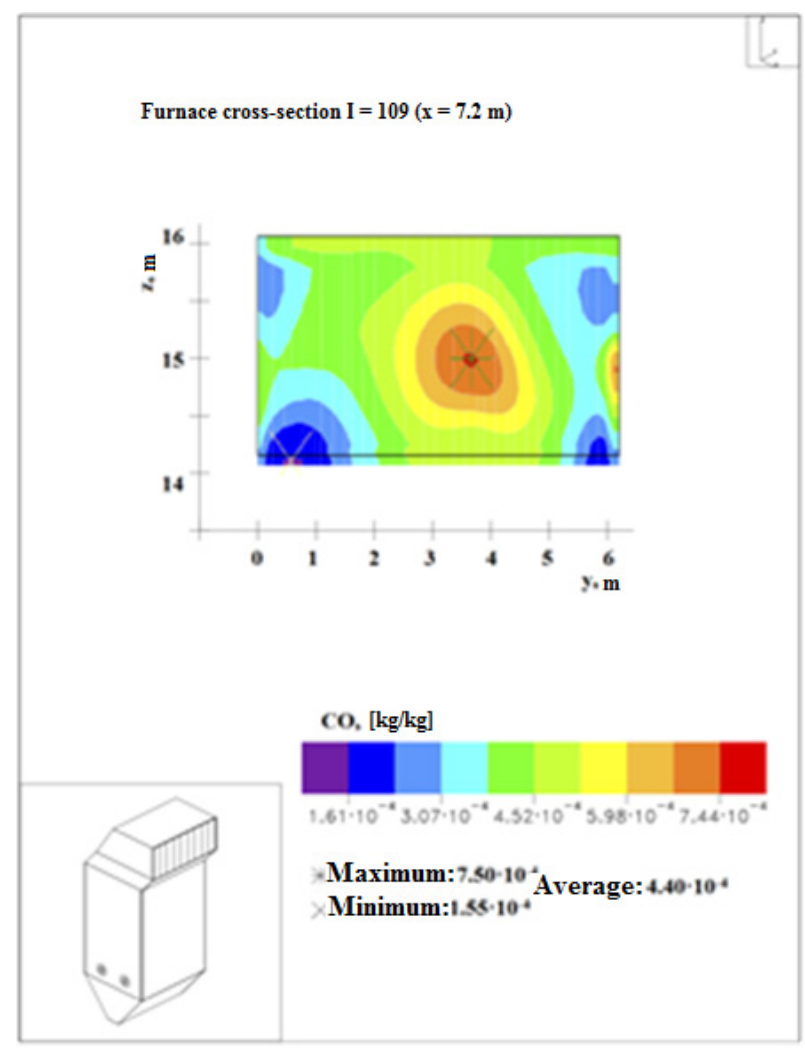

b)

Figure 4 - $\mathrm{CO}$ concentration distribution in cross sections:

a) burners, b) at the outlet of the combustion chamber 


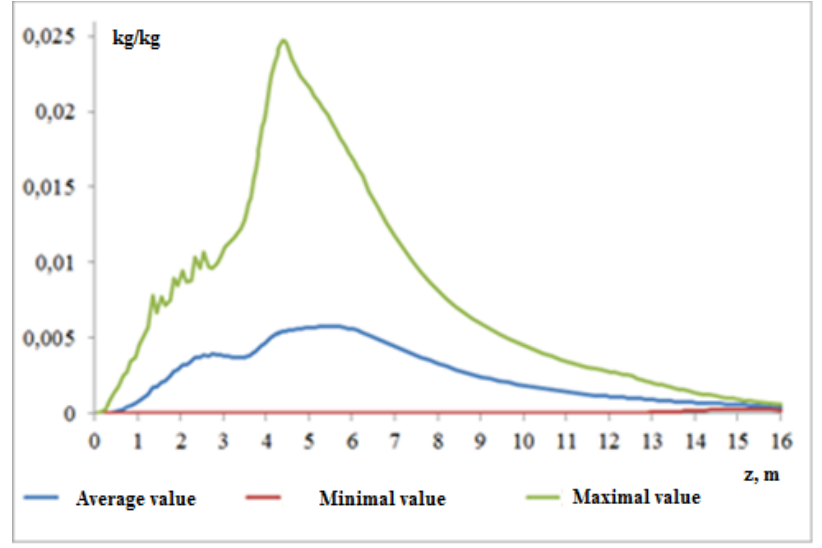

Figure 5 - The distribution of the carbon monoxide concentration $\mathrm{CO}$ in height of the combustion chamber
The analysis of figures 4-5 shows that the maximum concentration of carbon monoxide $\mathrm{CO}$ takes in the central section of the region of the burners, because there are higher temperatures, there is a large concentration of carbon fuel and oxygen oxidizer. As a result, in the area of burner the concentration of $\mathrm{CO}$ takes the value equal to $4.7^{*} 10^{-3} \mathrm{~kg} / \mathrm{kg}$. At the outlet of the combustion chamber decreases the concentration of CO. It is associated with a reduced concentration of oxygen and carbon.

Figure 6 shows the distribution of the concentration of carbon dioxide $\mathrm{CO}_{2}$ in sections of the burners and the outlet of the combustion chamber.

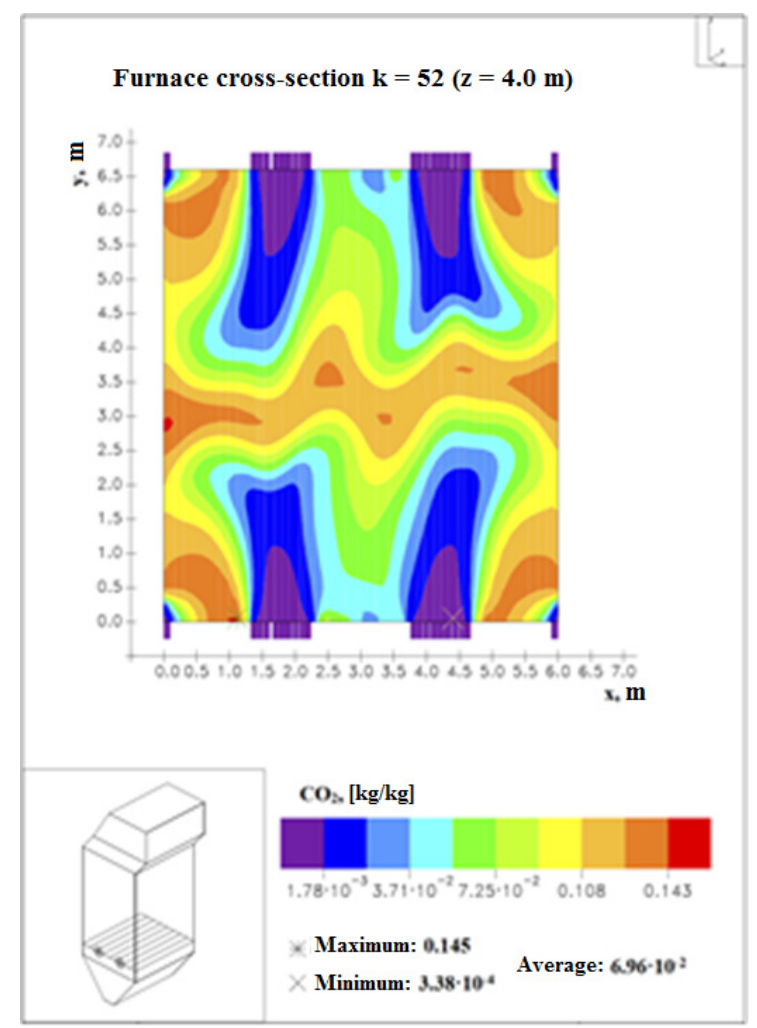

a)

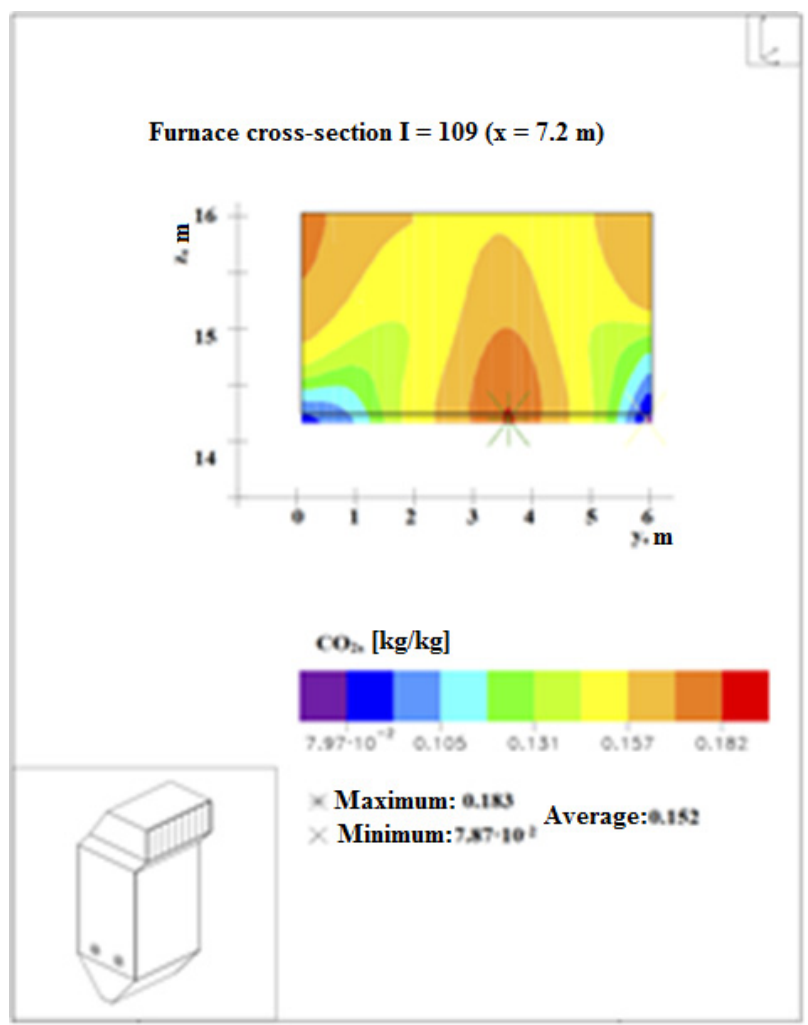

b)

Figure $6-\mathrm{CO}_{2}$ concentration distribution in the cross sections:

a) burners, b) at the outlet of the combustion chamber

Analysis of the figure 6 shows that the distribution of carbon dioxide $\mathrm{CO} 2$ is completely the opposite of the character of the distribution of oxide $\mathrm{CO}$. It is evident that in the belt of burners at a height of 4 meters in the concentration of carbon dioxide $\mathrm{CO} 2$ is minimal and amounts to $0.07 \mathrm{~kg} / \mathrm{kg}$. Maximum $\mathrm{CO}_{2}$ concentration is observed at the exit of the combustion chamber and has a value of $0.152 \mathrm{~kg} / \mathrm{kg}$. 


\section{Conclusions}

We investigated the field of concentrations of combustion products $\mathrm{CO}, \mathrm{CO}_{2}, \mathrm{NO}$ during combustion of coal-dust flame. It is shown that in the region of the burner main reactions occur reaction with carbon form carbon monoxide. The distribution pattern of carbon monoxide $\mathrm{CO}_{2}$ does not match the field $\mathrm{CO}$. It speaks about the differences in the formation of $\mathrm{CO}_{2}$ and $\mathrm{CO}$. The maximum concentration of $\mathrm{CO}$ at the burner takes a value equal to $4.7^{*} 10^{-3} \mathrm{~kg} / \mathrm{kg}$, and at the outlet of the combustion chamber, its average value of $4.40 * 10^{-4} \mathrm{~kg} / \mathrm{kg}$. In the zone of burners at a height of four meters concentration of carbon dioxide $\mathrm{CO}_{2}$ is minimal and is $0.07 \mathrm{~kg} / \mathrm{kg}$, whereas the concentration of $\mathrm{CO}$ in the oxide in the area takes a maximum value. Furthermore, unlike the distribution of carbon monoxide $\mathrm{CO}$, carbon dioxide $\mathrm{CO}_{2}$ concentration as it moves out of the combustion chamber increases and at the outlet assumes a maximum value equal to $0.152 \mathrm{~kg} / \mathrm{kg}$.

It was found that intensive mixing of fuel and oxidizer, which is created by turbulent flow of injected fuel mixture near the burner, and the high temperature of the core of the torch, creating favorable conditions for the formation of nitrogen oxides. In this region, the concentration of nitrogen oxides NO reaches $2201 \mathrm{mg} / \mathrm{Nm}^{3}$, and the output of the combustion chamber, its average value is 550 $\mathrm{mg} / \mathrm{Nm}^{3}$. The results will help power companies in Kazakhstan to solve important environmental problems and achieve cost-effective production of energy.

\section{References}

1 A.S. Askarova, E. I. Karpenko, V. E. Messerle et al. Plasma enhancement of combustion of solid fuels // Journal of High Energy Chemistry. - 2006. - Vol. 40. P. 111-118.

2 R. Leithner, H. Müller. CFD studies for boilers // Second M.I.T. Conference on Computational Fluid and Solid Mechanics. - Cambridge. - 2003. - P. 172-180.

3 R. Leithner, H. Müller, R. Heitmüller. Dreidimensionale Simulation von Dampferzeuger // VGB-Fachtagung: Dampfkessel und Dampfkesselbetrieb. - Essen. - 1993.

4 B. K. Aliarov, M. B. Aliarova. Incineration of Kazakhstan Coal at Tehermal Power Plants and Large Boilers (experience and problems). - Almaty. - 2011. P. 306.

5 A. S. Askarova, E. I. Karpenko, Yu. E. Karpenko et al. Mathematical modeling of the processes of solid fuel ignition and combustion at combustors of the power boilers // 7-th International Fall Seminar on Propellants. Explosives and Pyrotechnics. Theory and Practice of Energetic Materials. - China. - 2007. - Vol. 7. - P. $672-683$.

6 A. S. Askarova, V. E. Messerle, A. B. Ustimenko, S. A. Bolegenova, V. Yu. Maksimov. Numerical Simulation of the Coal Combustion Process Initiated by a Plasma Source // Journal of Thermophysics and Aeromechanics. - 2014. - Vol. 21. - Issue 6. - P.747-754.

7 A. Askarova, S. Bolegenova, V. Maximov et al. Numerical Modeling of Pulverized Coal Combustion at Thermal Power Plant Boilers // Journal of Thermal Science. - 2015. - Vol. 24. - P. 275-282.

8 A. Askarova, M. Gorokhovski, A. ChtabDesportes, I. Voloshina et al. Stochastic simulation of the spray formation assisted by a high pressure // 6-th International Symposium on Multiphase Flow. Heat Mass Transfer and Energy Conversion. Book Series: AIP Conference Proceedings. - 2010. - Vol. 1207. - P. 66-73.

9 R. Leithner, H. Müller, R. J. Heitmuller. Brennkammern einschließlich der NOxSchadstoffkinetik. VGB-Fachtagung: Dampfkessel und Dampfkesselbetrieb. - Essen. 1993. - P. 152.

10 H. Müller. Numerische Simulation von Feuerungen. CFD-Vorlesung. TU. Braunschweig: IWBT. - 1997. - P. 8.

11 H. Müller. Numerische Berechnung dreidimensionaler turbulenter Strömungen in Dampferzeugern mit Wärmeübergang und chemischen Reaktionen am Beispiel des SNCR-Verfahrens und der Kohleverbrennung: Fortschritt-Berichte VDI-Verlag. 1992. - Vol. 6. - № 268. - P. 158.

12 F. Lockwood, N. Shah. An improved flux model for calculation of radiation heat transfer in combustion chambers // ASME-AIChE Heat Transfer Conf.: ASMEPaper. - Salt Lake City. - 1976. - P. 2-7.

13 S. Patankar. Numerical heat transfer and fluid flow. Hemisphere Publishing Corporation. New York. 1980. - P. 152.

14 J.W. Mitchell, J.M. Tarbell. A kinetic model of nitric oxide formation during pulverized coal combustion // AIChE Journal. - 1982. - Vol. 28. - P. 302-320.

15 A. Askarova, E. Karpenko, Ye. Lavrishcheva, V. Messerle, A. Ustimenko. Plasma-supported coal combustion in boiler furnace // IEEE Transactions on Plasma Science. - Vol. 35. 2007. - P. 1607-1616.

16 A. Askarova, V. Messerle, A. Ustimenko, A. Nagibin. Pulverized coal torch combustion in a furnace 
with plasma-coal system // Thermophysics and Aeromechanics. - Vol.7. 2010. - P. 435-444.

17 A. S. Askarova, S. A. Bolegenova, A. Bekmuhamet, V. Yu. Maximov. Mathematical simulation of pulverized coal in combustion chamber // Procedia Engineering. - 2012. - Vol. 42. - P. 1259-1265.

18 A. S. Askarova, S. A. Bolegenova, A. Bekmuhamet, V. Yu. Maximov, Sh. S. Ospanova. Numerical research of aerodynamic characteristics of combustion chamber BKZ-75 mining thermal power station // Procedia Engineering. - 2012. - Vol.42. - P. 1250-1259.

19 A. S. Askarova, S. A. Bolegenova, S. Bolegenova, A. Bekmukhamet, V. Yu. Maximov, M. T. Beketayeva. Numerical experimenting of combustion in the real boiler of CHP // International Journal of Mechanics. - 2013. - Vol. 7. - P. 343-352.

20 A. Askarova, S. Bolegenova, A. Bekmukhamet, Yu. V. Maximov, M. Beketayeva. Sh, Ospanova. Z.K. Gabitova. Investigation of turbulence characteristics of burning process of the solid fuel in BKZ 420 combustion chamber // WSEAS Transactions on Heat and Mass Transfer. - 2014. - Vol. 9. - P. 39-50.

21 A. S. Askarova, A. Bekmukhamet, S. A. Bolegenova, M. T. Beketayeva, Yu. V. Maximov, Sh. S. Ospanova, Z. K. Gabitova. Numerical modeling of turbulence characteristics of burning process of the solid fuel in BKZ420-140-7c combustion chamber // International Journal of Mechanics. - 2014. - Vol. 8. - P. 112-122. 